\title{
FEDCHENKO Oleksiy,
}

Ph.D in Law, Senior Lecturer of Fire Training Department, National Academy of Internal Affairs VODOPYANOVA Tetiana,

Lecturer of Fire Training Department, National Academy of Internal Affairs

\section{SHTOMA Vadym}

Lecturer of Fire Training Department, National Academy of Internal Affairs

e-mail: prontenko-kostya@ukr.net

\section{THE EFFECTIVENESS OF THE METHODICAL SYSTEM OF CADETS' WEIGHT LIFTING TRAINING IN THE PROCESS OF PHYSICAL EDUCATION}

Abstract. Introduction. The results of the effecPiveness of the methodical system of teaching of cadets of kettlebell lifting in the process of physical education, which is oriented on the personality of a future officer who has a high level of physical and methodological preparedness, has fitness and health competencies for the implementation of physical education and sports in the sphere of professional activity was highlights in the article. Two experimental (EG1, $n=29, E G 2, n=33$ ) and control (CG, $n=57)$ groups of cadets of the S.P. Korolev Zhytomyr Military Institute aged 18-24 were formed for testing the effectiveness of the methodical system.

The purpose of the article is to investigate the effec?tiveness of the methodical system of kettlebell lifting training of cadets of higher military educational insti?utions of in the process of physical education.

Methods: Theoretical analysis and generalization of scientific and methodical literature, pedagogical supervision, pedagogical experiment, testing, methods of mathematical statistics.

Results. The positive influence of kettlebell lifting exercises on the success of cadets' study is proved - for all the studied blocks of disciplines in cadets of EG1 and EG2 at the end of the experiment the average score is significantly the same with the cadets of CG ( $p>0.05)$. This shows that rationally organized classes by the methodical system allow combining classes in kettlebell lifting training not only without negative consequences for the educational process, but also contribute to the improvement of the results of the study of various disciPlines.

The best level of methodological preparedness of the cadets of EG1 and EG2 at the end of the experiment, compared with the CG, was established based on the results of the assessment of the quality of the metho?ological task: $86.1 \%$ of the methodologically trained cadets were detected in EG1, 54.5\% of the metho?ologically trained cadets - in EG2, and only $31.6 \%$ - in $C G$, which testifies to the superiority of occupations by the methodological system over the current system for improving the level of methodological preparedness of cadets - future managers of physical training courses.

It was found out that the assessments of unit commanders regarding the efficiency of the tasks of the service during the experiment period for cadets of EG1 and EG2 were significantly better than cadets of $C G$ according to the indicators of individual psychological, moral, personal qualities, executive discipline and state of health $(p<0,05-0,001)$.

Originality. For the first time, the positive influence of kettlebell lifting exercises by the experimental methodical system on the improvement of the indicators of the success of study, methodical preparedness and service activity of the cadets has been proved.

Conclusion. Experimental testing of the methodical system in the process of forming a pedagogical experiment has shown its more positive effect, compared with the current system of physical training, for improving the indicators of success of study, methodical prepa?edness and service activity of cadets.

Keywords: methodical system of training, kettlebell lifting, cadets, physical education, success of study, methodical preparedness, service activity.

Одержано редакиією 12.10.2018 Прийнято до публікаиіï 19.10.2018

DOI 10.31651/2524-2660-2018-14-80-87

ORCID 0000-0002-8742-7773

\section{COBГIPA Cвitaaha,}

доктор педагогічних наук, професор,

Уманський державний педагогічний університет імені Павла Тичини

e-mail: sovgirasvitlana@gmail.com

ORCID 0000-0001-6606-3221

\section{ПОАІщук Омена,}

кандидат педагогічних наук, доцент,

Уманський національний університет садівництва e-mail: pol.elena@i.ua

УДК 378:[(34+33)(07)](043.3)

\section{ДІАГНОСТИКА СФОРМОВАНОСТІ ПРАВОВОӤ КОМПЕТЕНТНОСТІ МАЙБУТНІХ МЕНЕДЖЕРІВ АГРАРНОГО УНІВЕРСИТЕТУ}

у статті розкрито діагностику сорормованості правової компетентності майбутніх менеджерів аграрного університету на основі формувального експерименту. Розроблено програму формування правової компетентності майбутнъого менеджера у аграрних університетах. Розкрито поетапність проведення формувального експерименту з визначення рівнів сформованості компонентів правової компетентності студентів аграрного університету. Висвітлено проиес експериментальної роботи з визначення рівнів сформованості мотиваиійноиіннісного, когнітивно-комунікативного та практично-діяльнісного компонентів. Доведено статистичну достовірність отриманих результатів. 
Ключові слова: правова компетентність; майбутні менеджери; аграрний університет; компоненти правової компетентності; програма формування правової компетентності.

Актуацьність. Правова компетентність майбутнього менеджера передбачає знання і виконання ним соціальних норм і правиц поведінки, які санкціонуються або встановлюються державою відповідно до його прав, обов'язків і повноважень. У той же час слід зазначити відсутність такої компетентності у переважної кількості менеджерів, а також відсутність системи формування правової компетентності майбутнього менеджера. Компетентнісний підхід в організації правової підготовки майбутнього менеджера відбивається у вирішенні першочергової проблеми створення системи правової держави через вищу аграрну освіту. У цьому зв'язку проблема підвищення рівня і якості правової підготовки менеджерів набуває особливої актуацьності.

Анапіз напрацювань науковців. $\mathrm{Pi}$ зні аспекти проблеми дослідження розгмядалися у працях багатьох дослідників, зокрема: формування правової культури та правосвідомості особистості (В. Безбородий [1], О. Ганзенко [2], Н. Коваленко [3], В. Одарій [4]); особливості навчально-виховного процесу та правове виховання особистості (I. Бех [5], Ю. Сурмяк [6]); формування правових знань (О. Скакун [7]), викладання правових дисциплін (А. Колодій [8]). Результати аналізу наукової цітератури свідчать, що система правової підготовки майбутнього фахівця повинна бути співвіднесена 3 реаліями сучасних вимог щодо високого рівня його професіоналізму, який передбачає і відповідну його правову освіту. Тому одним із завдань університетів $\epsilon$ підготовка фахівця, який володіє правовою компетентністю як важливою складовою професійної компетентності.

Мета: на основі формувального експерименту здійснити діагностику сформованості правової компетентності майбутніх менеджерів аграрного університету.

Дия вирішення поставленої мети використовувалися такі методи та методики: у експериментальній групі студентам цілеспрямовано, поетапно пропонувалися професійні завдання, що забезпечують основу дия подальшого розвитку менеджера, готового до здійснення професійних функцій у аграрній сфері. у контрольній групі студентів заняття 3 правових дисциплін характеризувалися традиційним змістом, 3 використанням традиційних форм і методів роботи.

Здійснювалась перевірка: оновленого змісту дисциплін: "Адміністративне право" $з$ посиленням акцентів на Конституційному праві України, Кримінальному праві; "Трудове право" - Цивільному праві, Соціально-правовому забезпеченні населення, "Господарське право" - Житцовому праві, Юридичній деонтології, Сімейному та Екологічному праві для формування правової компетентності майбутнього менеджера в умовах аграрного вищого навчального закладу. Вихідним положенням виступало твердження, що заняття 3 правознавства в системі професійної підготовки майбутніх менеджерів, забезпечують формування компонентів правової компетентності (мотиваційно-ціннісного, когнітивнокомунікативного, практичнодіяльнісного) у кожного студента.

Протягом усього експериментального циклу проводимося цілеспрямоване спостереження за студентами під час занять і позааудиторних заходів та оцінювання іх діяльності з метою виявлення динаміки сформованості у них правової компетентності.

Результати дослідження. Визначаючи критерії правової компетентності (знання, вміння, якості особистості, досвід) ми керувалися ідеями та принципами теорії менеджменту, практичної педагогіки i вимог Державного освітнього стандарту. Сформованість правової компетентності була відстежена за допомогою відповідності видімених компонентів правової компетентності та їх показників.

В якості залежних змінних характеристик виступали рівні сформованості правової компетентності майбутнього менеджера - низький, середній, високий; в якості незалежних - оновлений зміст правових дисциплін, позааудиторна робота.

Основними складовими дослідження ефективного формування професійної компетентності були: засвоєння змісту навчальних програм з правових дисципмін; організація самостійної роботи студентів 3 метою формування активної професійної позиції щодо правових пробцем в процесі професійної економічної 
діяльності в аграрній сфері; організація практичної роботи студентів 3 метою формування професійної позиції і самооцінки; здійснення взаємодії викладачів і студентів.

Дия реалізації цих складових розробмено програму формування правової компетентності майбутнього менеджера у аграрних університетах, яка включає п'ять основних блоків:

- установчий - визначення потреби регіону у менеджерах зовнішньоекономічної діяльності різних рівнів і служб; підбір навчальних програм,

- діагностичний - діагностика індивідуально-особистісних особливостей студентів, виявцення спрямованості особистості, формування загальної програми розвитку правової компетентності,

- теоретичний - вивчення теоретичних основ компетентнісного підходу, формування методичного інструментарію,

- практичний - апробація активних методів формування правової компетентності майбутнього менеджера, реалізація навчальних програм,

- блок оцінки ефективності - стабімізація позитивних змін, порівняння попередніх прогнозів з отриманими результатами, закріплення позитивних змін, експертна оцінка якості правової компетентності майбутніх менеджерів.

Експериментальна робота умовно подікена на етапи: перший (1-2 курс), другий (3 курс), третій (4 курс).

Перший етап - формування професійної правової обізнаності, знайомство студентів 3 різними сторонами професійної діяльності, їх моральним і правовим наповненням. Основна увага на цьому етапі приділялася розвитку властивостей і якостей, що входять в когнітивно-комунікативний компонент. На цьому етапі студенти набували досвіду репродуктивної діяльності, яка визначама здатність відтворювати і застосовувати отримані знання на практиці.

У процесі формування правової компетентності на цьому етапі переважно реалізовувалися традиційні форми і методи навчання (цекції, семінарські, цабораторно-практичні заняття), на яких вирішувалися різноманітні професійні завдання. Робота 3 формування правової компетентності студентів знаходица своє продовження під час позааудиторних заходів, таких як вечори, конкурси, вікторини, олімпіади тощо.

Інтегративним критерієм сформованості правової компетентності на цьому етапі виступала здатність студентів відтворювати отримані знання, використовувати іх при вирішенні типових завдань, володіння способами і прийомами дій, які оцінювалися за успішності виконання контрольних робіт, відповідями на заняттях.

ДАя вирішення завдань етапу розроблена система занять за темами: "Вступ

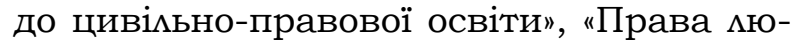
дини як загальнолюдська цінність", "Мотивація у професійній діяльності" та ін. На всіх запропонованих заняттях використовувалися елементи соціально психологічного тренінгу для зняття психологічних бар'єрів у спілкуванні, створення певного комунікативного настрою студентів, атмосфери доброзичиивості, розкутості, ставилися дискусійні питання про статус громадянина в сучасному суспільстві, про значення професійного спілку-

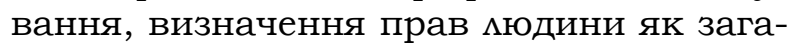
иьнолюдської цінності.

Комунікативний складник правової компетентності студентів, показниками якого $\epsilon$ ціннісне ставлення до професії та ii правового регулювання, комунікативність, уміння планувати свою діяльність і здатність критично оцінювати ії результати, діагностувався нами за допомогою модифікованої методики Т. Дубовицької і методики оцінки комунікативних і організаторських здібностей, розробленої В. Синявським і Б. Федоришиним.

Результатом першого етапу експериментальної роботи з формування у майбутніх фахівців правової компетентності стали зміни, виявлені в процесі діагностики: у багатьох студентів проявився інтерес не тільки до правових знань, але і до правових вмінь; поповнилися уявлення студентів про значення професійного спілкування.

Однак мотиви досягнення й афіліації були актуалізовані не у всіх студентів, що послужияо орієнтиром дмя подальшої роботи. Поряд, 3 аналізом поставцених на початку етапу завдань, діагностика показала й інші зміни стану правової компетентності в експериментальній групі: когнітивного складника - відбулося оволодіння студентами правовими знаннями, категоріями, пов'язаними 3 їхньою майбутньою професійною діяль- 
ністю; змінилося їнє ставлення до права і правових норм; комунікативного складника - студенти ознайомилися 3 основними принципами ведення дискусії, аргументованого доказу своєї точки зору.

Для виявлення рівня сформованості когнітивно-комунікативного компонента правової компетентності проведено тестування дмя визначення правових знань студентів. Крім тестових завдань закритого типу, розроблено опитувальник, що включав в себе питання правової спрямованості без вказівок варіантів відповідей.

Узагальнені результати методів і методик діагностики когнітивнокомунікативного компонента правової компетентності студентів, отримані після проведення першого етапу реалізації програми формувального експерименту показані на рис. 1.

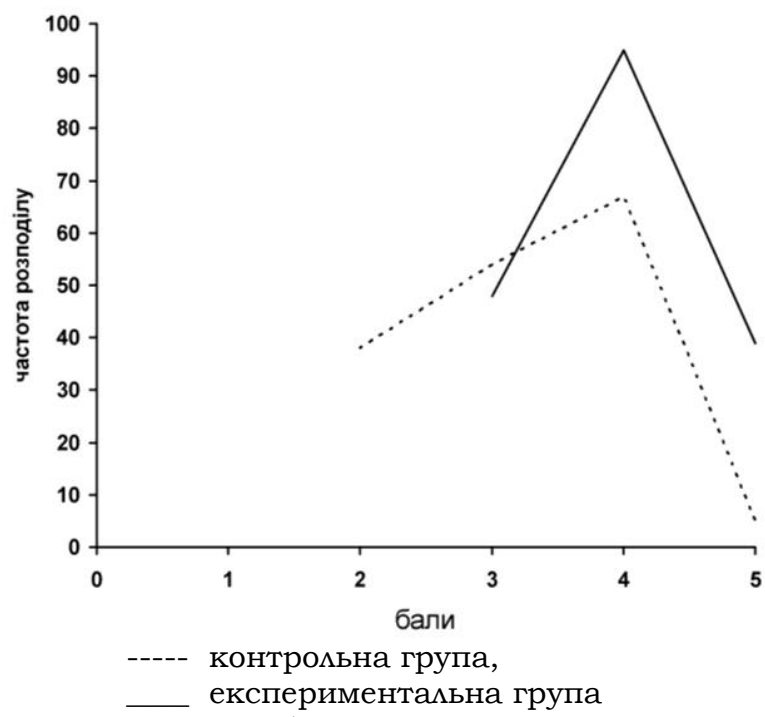

Рис. 1. Розподіл балів за рівнем сформованості мотиваційно-ціннісного компоненту правової компетентності студентів

Отже, узагальнений рівень сформованості правової компетентності студентів аграрного університету за когнітивно-комунікативним компонентом в експериментальній групі становить (в бамах): $\mathrm{H}_{\mathrm{e}}{ }^{0}=3,95 \quad(79,0 \%) ;$ контрольній $\mathrm{H}_{\mathrm{K}}{ }^{0}=3,24 \quad(64,8 \%)$. Різниця між ними склала 14,2 \%, яка на етапі формувального експерименту є суттєвою, що впливає на результативність сформованості правової компетентності студентів аграрного університету.

Після проведення першого етапу формувального експерименту в експериментальній групі динаміка позитивних змін більш істотна. Так, в експериментальній групі відсотковий приріст у порівнянні з контрольною групою за балом 5 склав $18,38 \%, 4-11,35 \%$.

Аналізуючи динаміку рівня сформованості когнітивно-комунікативного компонента правової компетентності студентів, можна зробити висновок, що в експериментальній групі процес набуття правових знань здійснювався швидше i ефективніше за рахунок активного використання різних форм освітньої діяльності, інтегрованих занять, введення питань правової спрямованості у зміст дисциплін практичної та професійного циклу, що сприяло розширенню, поглибменню та системності правових знань студентів.

В результаті проведених занять кількісні показники рівнів правової компетентності у майбутніх фахівців істотно змінилися у бік збільшення кількості студентів, що характеризувалися високими та середніми балами за рахунок зменшення кількості студентів, які раніше характеризувалися низькими балами. Звідси можна зробити висновок, що запропонована нами система занять на першому етапі формування правової компетентності майбутніх фахівців відповідає меті і завданням цього етапу експерименту.

Другий етап формувального експерименту спрямований на набуття елементів особистого професійно-правового досвіду, усвідомлення професійнозначущих особистісних якостей, власних можливостей і здібностей. Цей етап професійного становлення передбачає, в основному, формування мотиваційноціннісного компонента правової компетентності майбутнього менеджера. На цьому етапі провідне місце займали методи і прийоми, спрямовані на розвиток навчально-творчих здібностей. Студенти опановували методикою мокального моделювання та реалізації морального розвитку особистості, регулювання правових взаємин у колективі, професійноморального самовиховання і правової самоосвіти.

Вирішення завдань другого етапу здійснювалося за допомогою спеціально організованих занять, 3 використанням активних методів навчання (дискусій, імітаційних вправ, елементів соціальнопсихологічного тренінгу). Крім того, мотиваційно-ціннісний компонент правової компетентності студентів, що відображає емоційно-чуттєві прояви особистості сто- 
совно до права, оцінку значимості правової компетентності в діяльності фахівця аграрної сфери, діагностувався за допомогою професійних завдань.

В якості пріоритетних методів формування у студентів правової компетентності обрано дискусію, яка передбачає аналітико-синтетичну діяльність студентів, і імітаційні вправи, ділові ігри, тренінг. В якості допоміжних методів використовувалися діалог, бесіда, спостереження, тестування.

У процесі другого етапу формувального експерименту 3 розвитку мотиваційно-ціннісного компонента правової компетентності проведено анкетування, результати якого показали, що 58,7 \% студентів експериментальної групи виявили зацікавленість у вивченні правових дисциплін, зазначивши необхідність знання права для загального розвитку, для майбутньої професійної діяльності, для вирішення конфміктних ситуацій, що виникають у житті.

Вивчення правових дисциплін реалізовувалося в системі: цекції, семінари, мабораторно-практичні заняття, самостійна робота (включаючи навчальну $\mathrm{i}$ науково-дослідну), олімпіади з права, виробнича практика, підсумкова атестація.

Результатом експериментальної роботи з формування у майбутніх фахівців правової компетентності на другому етапі виявилися такі зміни: студенти стали більш вільно оперувати категоріями, пов'язаними 3 їхньою майбутньою професійною діяльністю, усвідомили необхідність правової підготовки як майбутнього менеджера аграрної сфери.

Узагальнені показники сформованості мотиваційно-ціннісного компонента правової компетентності майбутніх менеджерів, отримані в процесі другого етапу формувального експерименту, показано на рис. 2.

Отже, Узагальнений рівень правової компетентності майбутніх менеджерів за мотиваційно-ціннісним компонентом в експериментальній групі становить (в балах): $\mathrm{H}_{\mathrm{e}}{ }^{0}=3,62$ (74,4\%); контрольній $\mathrm{H}_{\mathrm{K}} \mathrm{O}=3,1$ (62,0 \%). Різниця між ними склала $12,4 \%$, яка на етапі формувального експерименту є суттєвою, що впливає на результативність сформованості правової компетентності студентів аграрного університету.

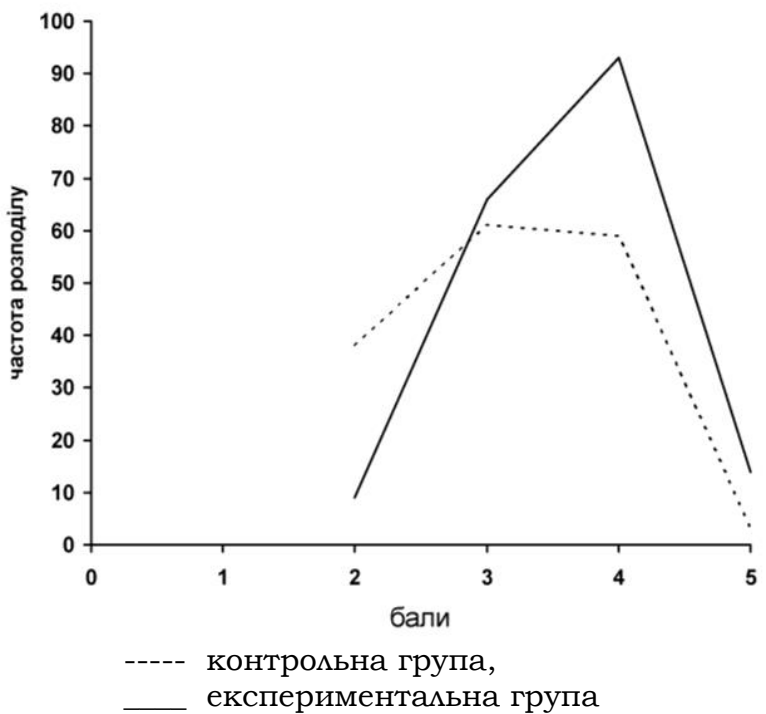

Рис. 2 Розподіл балів за рівнем сформованості мотиваційно-ціннісного компоненту правової компетентності студентів

Експериментальна робота на третьому етапі формування правової компетентності полягала в організації впливу на формування практично-діяльнісного компоненту, який інспірує розвиток професійних умінь проведення ділових зустрічей, відстоювання своєї точки зору на основі норм законодавства, досягнення угоди сторін, залучення студентів до процесу оволодіння етикою професійного спілкування, грамотним застосуванням знань на практиці, узгодженням власної діяльності 3 нормами права, правовою активністю, діагностувався нами за допомогою складених і запропонованих для вирішення студентам юридичних завдань, завдань по складанню правових документів. Правову активність як показник практично-діяльнісного компоненту правової компетентності ми оцінювали за ініціативністю та участю студентів у різних заходах правового характеру, які проводилися в рамках реалізації розробменої нами програми формування правової компетентності майбутніх менеджерів в аграрному університету.

Засоби, які використовуються нами на третьому етапі формування правової компетентності, були спрямовані на створення квазіпрофесійної діяльності (адвокат, прокурор), що сприяло емоційній насиченості та активізації інтересу студентів на заняттях.

Важливим напрямом у проведенні експериментального дослідження було проходження практики. 
На третьому етапі реалізації програми формувального експерименту розвиток професійних умінь і навичок забезпечувався здійсненням різних видів діяцьності: навчально-професійної, діяльності в період практики, діяльності, пов'язаної з участю у позааудиторних заходах правового характеру. Студенти залучалися до виконання різноманітних творчих завдань, проектів, навчальнодослідної роботи, брали участь у рольових іграх, тренінгових вправах, диспутах та дискусіях.

Результатом експериментальної роботи 3 формування у студентів правової компетентності на третьому етапі виявимися такі зміни: студенти оволоділи способами міжособистісної взаємодії, вміннями організації діалогів, полілогів, бесід; набули досвіду застосування правових знань у конкретних професійних ситуаціях та ї аналізу; багато студентів овомоділи вміннями самовираження в професійній діяльності.

Діагностика показала значні зміни стану й інших компонентів правової компетентності: мотиваційно-ціннісного компонента - у 50,7\% студентів ЕГ, (20,4 \% КГ) спостерігалися активність в ініціації спілкування і здатності до його підтримки, що свідчить про актуалізацію мотивів афіліації та досягнення; близько $30,7 \%$ студентів ЕГ, $(16,4 \%$ КГ) демонстрували потребу у встановленні контактів i ix підтримці; когнітивнокомунікативного компонента - у студентів спостерігалася орієнтація на використання правових знань в організації та підтримці професійних контактів, їхні висловлювання стали більш аргументовані.

Узагальнені показники сформованості правової компетентності майбутніх менеджерів за практично-діяльнісним компонентом, відображено на рис. 3.

Отже, узагальнений рівень сформованості правової компетентності майбутніх менеджерів в аграрному університеті за практично-діяльнісним компонентом в експериментальній групі складає (в балах): $\mathrm{H}_{\mathrm{e}}{ }^{0}=3,59$ (71,8 \%); контрольній $\mathrm{H}_{\mathrm{K}}{ }^{0}=3,24$ (64,8 \%). Різниця між ними склала 7,0 \%, яка на етапі формувального експерименту є суттєвою, що впливає на результативність сформованості пра- вової компетентності студентів аграрного університету.

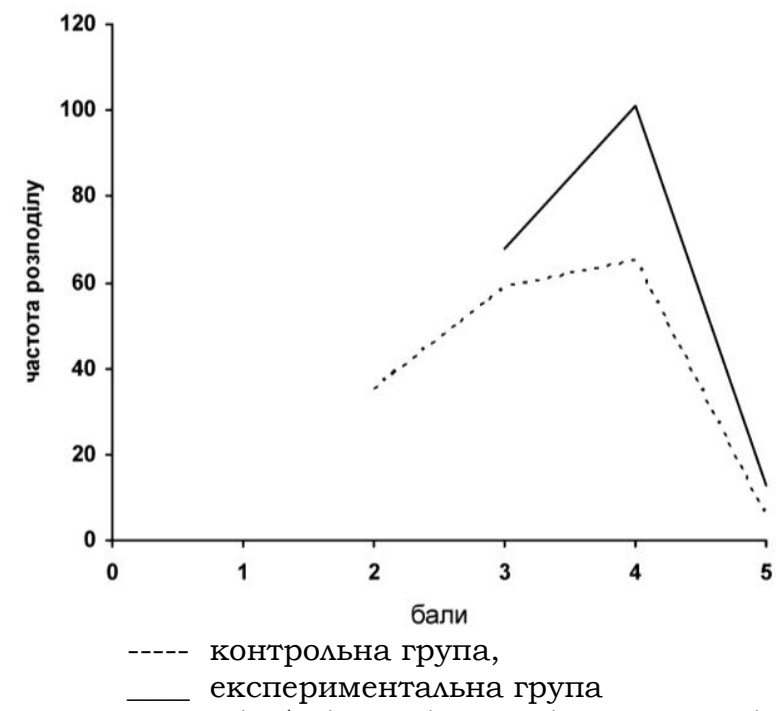

Рис. 3 Розподіл балів за рівнем сформованості мотиваційно-ціннісного компоненту правової компетентності студентів

Отримані дані свідчать, що правова компетентність майбутніх менеджерів за мотиваційно-ціннісним критерієм в експериментальній групі складає 72,4 \%, що складає високий рівень, контрольній 62,0 \%, що відповідає середньому рівню.

Когнітивно-комунікаційний компонент правової компетентності студентів аграрного ВНЗ в експериментальній групі складає 79,0 \%, що складає високий рівень, контрольній - 64,8 \%. Це показник середнього рівня.

Практично-діяльнісний компонент правової компетентності студентів аграрного ВНЗ в експериментальній групі складає $71,8 \%$, що складає високий рівень, контрольній - 64,8 \%. Це показник середнього рівня.

Порівняльний аналіз рівнів правової компетентності студентів аграрного університету за компонентами доводить, що між ними існує значна відмінність, яка потребує перевірки на достовірність. Дия цього використаємо критерій Пірсона.

Проведений розрахунок показав, що за мотиваційно-ціннісним компонентом він складає 54,8, когнітивнокомунікативним - 78,5, практичнодіяльнісним - 63,1. Отримані дані доводять, що на результати сформованості правової компетентності студентів аграрного університету у процесі формувального етапу експерименту впливали експериментальні чинники.

Дия унаочнення результати дослідження відображено на рис. 4. 


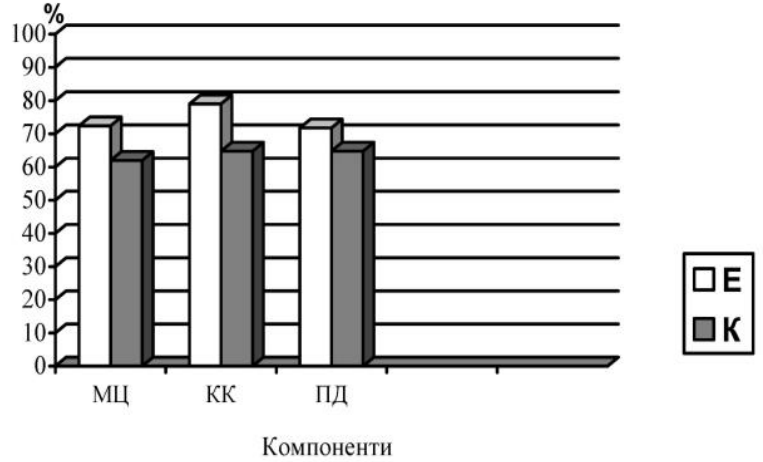

Рис. 4. Рівні правової компетентності майбутніх менеджерів зовнішньоекономічної діяльності за результатами формувального експерименту

На рисунку добре видно наближення до високого рівня правової компетентності студентів аграрного університету за мотиваційно-ціннісним, когнітивнокомунікативним, практично-діяльнісним компонентами в експериментальній, середнього в контрольній групах та значну різницю їх показників. Різниця між мотиваційно-ціннісним компонентом експериментальної та контрольної групи складає 10,4\%, когнітивнокомунікативним - $14,2 \%$, практичнодіяльнісним - 7,0 \%. Це означає, що між рівнями сформованості правової компетентності студентів аграрного університету за компонентами існує значна відмінність.

Отже, формувальний етап експерименту показав високий рівень правової компетентності студентів аграрного університету за мотиваційно-ціннісним, когнітивно-комунікативним, практичнодіяльнісним компонентами в експериментальній та середній - у контрольній групах.

Результати експерименту вказують на ефективність розробленої програми формування правової компетентності студентів аграрного університету, на позитивні зміни в рівнях сформованості їх правової компетентності в експеримента^ьній групі.
Перспективи подамьших досліджень вбачаємо у дослідженні особистісних якостей менеджерів у процесі їх професійної діяльності.

\section{Список бібліографічних поснмань}

1. Безбородий В.О. Формування професійної правової культури керівників органів внутрішніх справ : автореф. дис. ... канд. пед. наук. Харків, 2001. 18 c.

2. Ганзенко О.О. Формування правової культури особи в умовах розбудови правової держави : автореф. дис. ... канд. юрид. наук. Київ, 2003. 20 с.

3. Коваленко Н.Ю. Формування правосвідомості і правової культури студентів неюридичних вищих навчальних закладів. Часопис Київського універcumemy права. 2008. № 1. С. 53-58.

4. Одарій В.В. Правова культура професійної діяльності педагога як педагогічна проблема. Наша школа. 2002. № 5. С. 11-13.

5. Бех І.Д. Виховання особистості. Київ: Аибідь, 2008. 848 c.

6. Сурмяк Ю.Р. Взаємодія вищих професійних учиАищ та органів внутрішніх справ у правовому вихованні учнів : дис. ... канд. пед. наук. Дрогобич, 2009. 257 c.

7. Скакун О.Ф. Теорія держави і права. Харків: Консум, 2001. 656 с.

8. Колодій А.М. Конституція і розвиток принципів права України (методичні питання) : автореф. дис. ... д-ра наук. Київ, 1999. 36 с.

\section{References}

1. Bezborodii, VO (2001). Formation of the professional legal culture of the heads of internal affairs bodies (Ph.D dissertation). Thesis. Kharkiv. 18 p.

2. Ganzenko, O.O. (2003). Formation of the legal culture of a person in conditions of development of the rule of law. (Ph.D dissertation). Thesis. Kiev. 20 p.

3. Kovalenko, N.Yu. (2008). Formation of legal consciousness and legal culture of students of nonlegal higher educational institutions. Journal of the Kyiv University of Law. 1. 53-58.

4. Odary, V.V. (2002). Legal culture of professional activity of a teacher as a pedagogical problem. Our school. 5. 11-13.

5. Bech, I.D. (2008). Parenting. Kyiv: Lybid. 848 p.

6. Surmayak, Yu.R. (2009). Interaction of higher professional schools and law enforcement bodies in legal education of students (Ph.D dissertation). Thesis. Drohobych. 257 p.

7. Skakun, O.F. (2001). Theory of state and law. Kharkiv: Consum. 656 p.

8. Kolodiy, AM (1999). Constitution and development of the principles of law of Ukraine (methodical questions) (Doctor Sciences dissertation). Thesis. Kiev. 36 p.

\section{SOVHIRA Svitlana, \\ Doctor in Pedagogy, Professor, \\ Pavlo Tychyna Uman State Pedagogical University e-mail: sovgirasvitlana@gmail.com \\ POLISHCHUK Olena, \\ Ph.D in Pedagogy, Associate Professor, \\ Uman National University of Gardening e-mail: pol.elena@i.ua}

\section{DIAGNOSTICS OF THE FORMATION OF THE LEGAL COMPETENCE OF FUTURE MANAGERS OF AN AGRARIAN UNIVERSITY}

Abstract. Diagnosis of the formation of the legal competence of future managers of the agrarian university on the basis of the molding experiment is disclosed in the article. The purpose is defined: on the basis of the molding experiment, to carry out the diagnostics of the formation of the legal competence of future managers of the agrarian university. Methods used: professional tasks, the organization of independent work of students, the 
organization of practical work, the interaction of teachers and students are applied. The program of formation of the legal competence of the future manager at agrarian universities has been developed. The step-by-step implementation of the molding experiment for determining the levels of component generation of the legal competence of the future manager at agrarian universities is disclosed. The process of experimental work on determination of levels of formation of motivational-value, cognitive-communicative and practical-activity components is ighlighted. Result: the forming stage of the experiment showed a high level of legal competence of students of the agrarian university for the motivational-value, cognitivecommunicative, practical-activity components in the experimental and medium - in the control groups. The statistical reliability of the obtained results is proved.

Keywords: legal competence; future managers; agrarian university; components of legal competence; program of formation of legal competence.

Одержано редакиією 12.06.2018 Прийнято до публікаиї̈ 19.06.2018

DOI $10.31651 / 2524-2660-2018-14-87-92$

ORCID 0000-0001-8387-267X

\section{ФЕДЯЄВА Марія Сергіївна,}

кандидат економічних наук, доцент кафедри економіки та міжнародних економічних відносин, Херсонський державний університет e-mail: Larienemf@gmail.com

\section{УДК 378.4}

\section{НАУКОВО-МЕТОДИЧНІ ОСНОВИ ПІДГОТОВКИ МАЙБУТНІХ МЕНЕДЖЕРІВ ДО УПРАВАІНСЬКОї ДІЯАЬНОСТІ}

У статті проаналізовано стан та завдання шоодо формування управлінської діяльності у майбутніх економістів. Розкрито особливості успішності реалізаиї магістерських програм за спеиіальностями: управління та адміністрування, менеджмент та адміністрування.

Доведено, шо ступінь успішності залежить від багатьох чинників, як один із провідних визначено ефрктивне науково-методичне забезпечення організаиії освітнього проиесу на економічних фракультетах. Обтрунтовано ключові компетентності майбутніх управліниів: кониептуальне мислення, дієвість та результативність; стійкість та емоиійна зрілість; зосередженість на майбутньому; уміння формувати корпоративну культуру; уміння приймати рішення; упровадження змін та інноваиій y роботу організаиї̈; розробка стратегій та планування; управління економічним проиесом y контексті поточних економічних реформ; уміння використовувати методи мотиваиії персоналу; управління підприємством, відділом, організаиією у контексті парадигми лідерства.

у досліджені визначено найбільш значуші шляхи формування викладачами управлінської діяльності в проиесі професійної підготовки студентів: постійна робота над змістом освіmu - відповідність його світовому та європейському рівню; оволодіння студентами базовими компетентностями в сорері управління, сучасне науково-методичне забезпечення освітнього проиесу на економічних факультетах; поєднання теоретичного, практичного $i$ наукового блоку підготовки управлінських кадрів.

Ключові слова: управлінська діяльність; компетентність; науково-методичне забезпечення; управління підприєиством; освітній проuec.

Постановка проблеми. Соціальноісторичні та політичні обставини самим активним чином впливають на реформу- вання вітчизняної системи освіти [1], на підготовку фахівців різних галузей виробництва, освіти, культури тощо. Перед сучасними закладами освіти постають нові соціально-професійні запити щодо підготовки керівних кадрів, які володіють необхідними уміннями й навичками управлінської діяльності. Одним із завдань вищої освіти в нашій країні $є$ підготовка конкурентоспроможних фахівців - керівників світового рівня, які здатні забезпечити результативну управлінську діяльність, очолюваних ними підприємств, корпорацій, холдингів та ін.

Аналіз останніх досліджень і пубмікацій. Проблема підготовки студентів до управлінської діяльності не є зовсім новою для вітчизняної науки. В цьому науковому полі проводилися дослідження, які розглядали систему підготовки управлінських кадрів як у вітчизняних закладах освіти ( . Карамушка, В. Олійник, $\Lambda$. Даниленко, $\Lambda$. Калініна та ін.), так і зарубіжних, зокрема у Великій Британії, Канаді та США (О. Ельбрехт, C. Бурдіно, В. Ткаченко) [2; 3].

мета статті - встановити основні складові (системи) науково-методичного забезпечення підготовки майбутніх менеджерів до управлінської діяльності визначивши підсистеми такої системи, педагогічні умови іï реалізації, а також розкрити сучасні технології навчання через форми, прийоми, методи і засоби впро- 